


«Um editor já desmascarado ou marcado»: a Livraria Moraes Editora e a censura

Autor(es): $\quad$ Ludovico, Sara

Publicado por: Imprensa da Universidade de Coimbra

URL

persistente: URI:http://hdl.handle.net/10316.2/40970

DOI: $\quad$ DOI:https://doi.org/10.14195/1645-2259_16_20

Accessed : $\quad$ 26-Apr-2023 08:10:20

A navegação consulta e descarregamento dos títulos inseridos nas Bibliotecas Digitais UC Digitalis, UC Pombalina e UC Impactum, pressupõem a aceitação plena e sem reservas dos Termos e Condições de Uso destas Bibliotecas Digitais, disponíveis em https://digitalis.uc.pt/pt-pt/termos.

Conforme exposto nos referidos Termos e Condições de Uso, o descarregamento de títulos de acesso restrito requer uma licença válida de autorização devendo o utilizador aceder ao(s) documento(s) a partir de um endereço de IP da instituição detentora da supramencionada licença.

Ao utilizador é apenas permitido o descarregamento para uso pessoal, pelo que o emprego do(s) título(s) descarregado(s) para outro fim, designadamente comercial, carece de autorização do respetivo autor ou editor da obra.

Na medida em que todas as obras da UC Digitalis se encontram protegidas pelo Código do Direito de Autor e Direitos Conexos e demais legislação aplicável, toda a cópia, parcial ou total, deste documento, nos casos em que é legalmente admitida, deverá conter ou fazer-se acompanhar por este aviso.








\section{Revista \\ de História \\ da Sociedade \\ e da \\ Cultura}




\title{
«Um editor já desmascarado ou marcado»: a Livraria Moraes Editora e a censura ${ }^{1}$
}

\section{«A publisher already unmasked or marked»: the Livraria Moraes Editora and the censorship}

\author{
SARA Ludovico \\ Bolseira de doutoramento da FCT \\ CHAM, FCSH, Universidade NOVA de Lisboa, Universidade dos Açores \\ saraludovico@gmail.com
}

Texto recebido em / Text submitted on: 04.04.2016

Texto aprovado em / Text approved on: 10.09.2016

Resumo: Na década de 50 um grupo de católicos delineou um projeto que se queria de "pensamento e ação", percorrendo várias etapas e disseminando ideias até à concretização do seu plano maior: criar uma revista. A aproximação deste grupo a António Alçada Baptista, que comprara uma antiga livraria, a Moraes, tornaria, anos depois, o sonho de O Tempo e o Modo possível. Mas foi primeiro no território da Editora Moraes, através do seu plano editorial, que este grupo de católicos "progressistas" manifestou, com o seu humanismo interventor, uma nova forma de ação política e artística. Se a identidade da própria editora se revela à luz do seu catálogo, o impacto cultural revolucionário e socialmente subversor pode ser medido através do peso da perseguição censória feita às suas publicações. As palavras dos censores confirmam a difícil posição da Moraes enquanto editora católica e enquanto "terceira via" no debate de ideias, na segunda metade do século $X X$ em Portugal.

Palavras-chave: Livraria Moraes Editora, censura, edição, Estado Novo, história do livro.

Abstract: In the 1950s a group of Catholics delineated a project combining "thought and action", covering various stages and disseminating ideas for the achievement of its ultimate aim: to create a magazine of ideas. This group's approach to António Alçada Baptista, who was to buy an old bookshop, Moraes, would some years later make the dream come true with the creation of O Tempo e o Modo. But it was in the publishing house Moraes, with its innovative editorial policy, that this group of progressive Catholics created a new form of political and artistic action with their interventionist humanism. If the publisher's identity was revealed in its catalog, its cultural revolutionary and socially subversive impact can be measured by the weight of the censorial persecution to which

1 Agradeço ao Dr. Paulo Tremoceiro, do Arquivo Nacional da Torre do Tombo, por toda a ajuda e disponibilidade, bem como às Doutora Teresa Seruya e Maria Lin Moniz pela cedência da base de dados dos relatórios depositados na Torre do Tombo. 
its publications were subject. The censors' comments confirm Moraes difficult position as a Catholic publishing house that became a "third way" in the debate of ideas in the second half of the $20^{\text {th }}$ century in Portugal.

Keywords: Livraria Moraes Editora, censorship, publishing, Portuguese Estado Novo, book history.

Aviso de porta de livraria

Não leiam delicados este livro

[...] os que andam aos pulinhos num pé só

com as duas castas mãos uma atrás e outra adiante, enquanto com a terceira vão tapando a boca

dos que andam com dois pés sem medo das palavras. [...]

De amor e de poesia e de ter pátria aqui se trata: que a ralé não passe este limiar sagrado e não se atreva a encher de ratos este espaço livre

Jorge de Sena

O poema em epígrafe foi publicado na obra Exorcismos de 1972, precisamente o único livro da célebre coleção "Círculo de Poesia”, publicado pela Editora Moraes, que se sabe ter sido apreendido. Nele, logo na abertura, o poeta deixa este aviso: transpor a página inaugural do livro é como transpor a porta de uma livraria. Uma livraria (tal como um livro) é quase sempre um lugar de muitas promessas e o simples ato de superar esse "limiar sagrado", que separa a esfera pública da cultura, o mundo exterior do mundo dos livros, significa entrar totalmente num "espaço livre", onde muitos dos condicionamentos sociais, políticos, morais e até legais desaparecem. Tal seria particularmente verdade em tempos de ditadura, num país como Portugal e numa livraria-editora como a Moraes.

A Livraria Moraes Editores e a revista O Tempo e o Modo são, juntamente com a Cooperativa de Difusão Cultural e Acção Comunitária Pragma², um dos projetos mais inovadores que, no âmbito sociocultural, os católicos organizaram em Portugal nos fins da década de 50 e inícios da década de 60. Nas palavras de Alçada Baptista: "um católico tinha uma missão a desempenhar

2 A Pragma foi fundada em abril de 1964, pelos compagnons de route Mário Murteira e Nuno Teotónio Pereira. Lembre-se ainda a publicação Direito à Informação, criada um ano antes, por Nuno e Natália Teotónio Pereira, que se dedicava sobretudo à divulgação de notícias sobre a guerra colonial em Angola (Lopes 2007: 25). 
no mundo ao serviço da verdade e da justiça que emanava da mensagem de Cristo" (Baptista 2000: 61), coincidindo com uma certa imagem do editor como "alguém cuja acção se pautava por um princípio de apostolado, no qual a cultura surgia como bem primordial a defender. O comércio tende a ser relegado para um lugar menor, embora não ausente do discurso" (Medeiros 2008: 798).

Apesar da história da Livraria Moraes não começar em 1958², quando António Alçada Baptista a adquire, juntamente com outros sócios, é nesse simbólico ano que tem início a "epopeia" editorial pela qual ficará conhecida e que representará "um acontecimento invulgar na História da Cultura em Portugal” (Almeida 2008: 112). Ao mesmo tempo, a livraria, até então especializada em livros de Direito, passa igualmente a funcionar como polo de discussão e de debate de ideias, desempenhando ainda, através de canais próprios, um importante papel na circulação de livros proibidos (Barata, Queirós 1994: 3):

Alçada Baptista criara um dos mais fecundos espaços de reflexão e debate existentes entre nós [...], lugar genuíno de debate e encontro de pessoas por vezes com percursos anteriores bastante diferenciados e perspectivas nem sempre coincidentes que se abriam para um largo espectro de acções tidas por necessárias para instalar o mundo novo (Cravinho 2004: 143).

Viviam-se em Portugal tempos de contestação e assistiu-se, nesse ano, com a candidatura presidencial do general Humberto Delgado, à maior mobilização contra o regime salazarista, a que alguns católicos entusiasticamente aderiram. Embora os primeiros tempos da livraria-editora tivessem sido marcados por dificuldades, o seu destino estava prestes a mudar, quando, um dia, a sua história se interceptou com a história de um grupo de jovens que sonhava fazer uma revista. Por essa altura, já a Livraria Moraes se havia tornado num sítio onde se podia encontrar "sem muito vasculhar e nada perguntar $[\ldots]$ autores estrangeiros de língua francesa ou traduzidos em francês que, se porventura se apresentassem em português, por certo não escapariam ao olhar rigoroso da censura e seriam pura e simplesmente proibidos" (Morais 2007: 110). Também para este grupo ${ }^{4}$, constituído por estudantes universitários de diversas faculdades, que partilhavam o gosto

\footnotetext{
A origem da livraria remonta a meados do séc. XIX, tendo começado numa mercearia na Rua da Rosa, em Lisboa.

4 Entre eles estão João Bénard da Costa, Nuno Bragança, Pedro Tamen, Nuno Portas, José Domingos Morais, Alberto Vaz da Silva, entre outros.
} 
pela literatura e pela arte e nutriam pelo Estado Novo um profundo desprezo, o Cristianismo era sobretudo um "gerador de inquietações e um fomentador de necessidades morais comuns aos outros homens” (Tamen 2007: 14).

Explorar as coleções da Livraria Moraes Editora significa repercorrer quase 30 anos da história do Portugal contemporâneo, sendo possível, através delas, captar o espírito de cada época, aceder a um novo tipo de filosofia religiosa, a um projeto consistente de revisão do discurso tradicional católico que, apesar da censura, e só talvez graças a um certo analfabetismo imperante na época, pôde circular, disseminar-se e influenciar as mentalidades. Através delas divulgaram-se autores e pensadores como Chesterton, Simone Weil e Hannah Arendt, editaram-se clássicos como os Pensamentos de Pascal e a Imitação de Cristo, fizeram-se antologias sobre o personalismo de Mounier, espalhou-se a mensagem do Vaticano II pela mão de teólogos como González Ruiz e do cristianismo revolucionário da Teologia da Libertação pela mão de Metz, deu-se voz a personalidades como Martin Luther King.

\section{Listas, relações e relatórios: um levantamento preliminar}

Até à data não existe uma lista exaustiva e completa dos livros que foram proibidos durante o período do Estado Novo. Tal tarefa seria, com certeza, uma empresa hercúlea, quando se pensa que só no opúsculo da Comissão do Livro Negro sobre o Regime Fascista dedicado aos livros proibidos, ao abrigo do decreto-lei 110/78 (de 16/5), com intuito de apurar e repor a verdade histórica ${ }^{5}$, os títulos ascendem à razão de bem mais de três milhares, contando com as publicações periódicas. A desorganização do sistema, as intervenções da polícia política, a dispersão do território e as falhas de comunicação entre os vários intervenientes nos processos censórios tanto na metrópole, como nas colónias, desdobraria ainda mais proibições e apreensões ${ }^{6}$.

Através deste mesmo opúsculo é possível ter uma perceção do panorama da censura, embora de forma lacunar, pois não só não é exaustiva, como os dados apresentados estão em bruto, ou seja, a uma lista ordenada alfabeticamente por apelido do autor correspondem títulos, sem quaisquer outras

5 Como é explicitado nesse diploma: "Visará o livro negro esclarecer a opinião pública sobre as violências e abusos praticados durante quase meio século em Portugal, bem como sobre os atos políticos e os atos de governação que conduziram o País a uma situação de crise nacional a que o 25 de Abril de 1974 veio pôr termo”. Relação das publicações em Comissão do Livro Negro sobre o Regime Fascista 1981: 13-115.

6 Veja-se o relato em primeira pessoa de Francisco Lyon de Castro em Ferrão, Oliveira e Fonseca 2015: 16. 
indicações como editora, ano de publicação, etc. Numa outra secção, surgem apenas títulos de obras, sem indicação do autor. Esta tarefa de "interesse nacional”, conforme se diz, e a apresentação crua e quase espontânea que se faz dos títulos proibidos vai, porventura, ao encontro do caráter de urgência que então se sentiria, de uma forma profunda e generalizada, em tornar público tudo quanto dissesse respeito ao esclarecimento político dos factos e dos acontecimentos que possibilitaram e mantiveram o regime fascista em Portugal. Conforme é explicitado na "Introdução", na origem desta lista está uma primeira Relação publicada pela Associação dos Editores e Livreiros Portugueses (AELP), embora a Comissão tenha levado a cabo algumas correções, admitindo porém que esta continue incompleta e que existam erros.

A Relação da AELP foi dada a lume ainda no rescaldo da revolução (junho de 1974), como forma de denúncia dos constrangimentos em que haviam trabalhado os profissionais do sector livreiro durante 48 anos e como chamada de atenção para o paradigmático quadro em que havia operado a cultura portuguesa e o próprio pensamento da elite intelectual. Diz-se na "Nota prévia":

A relação das obras $[\ldots]$ foi elaborada com base nos elementos que regularmente foram fornecidos pelas extintas Direcção dos Serviços de Censura e Direcção dos Serviços de Informação. Trata-se de um trabalho exaustivo, produzido com os dados de que dispomos, o que, necessariamente, não significará que se mostre isento de erros (AELP 1974: s.p.).

Corroborando uma certa ideia de premência, que impelia à divulgação a todo o custo do passado obscurantista da censura e dos tortuosos bastidores da edição em Portugal, superando mesmo dificuldades extremas como a escassez de papel ${ }^{7}$, esta lista parece funcionar como uma espécie de "exorcismo", um pedido de desculpas por tudo aquilo que editores e livreiros desejariam ter feito, mas que não puderam fazer, e até, devido ao clima vivido na altura, uma declaração pública mostrando de que lado estavam os livros (e, por extensão, os editores). Com efeito, esta Relação está ordenada alfabeticamente pelos títulos das obras proibidas de circular e, embora com escassa informação, inclui uma secção de "Editores ou distribuidores", por sua vez omitida no opúsculo da Comissão do Livro Negro.

\footnotetext{
"Pedimos desculpa pelo facto de, perante a escassez de papel, nos termos visto obrigados a apresentar esta obra em papel de cores diferentes. Supomos, porém, que a oportunidade do conteúdo supera, no interesse de todos, as dificuldades de forma que não conseguimos vencer" (cit. da "Nota prévia", s.p.).
} 
Também a investigadora Maria Luísa Alvim, no seu trabalho de mestrado, onde se propôs elaborar uma bibliografia e uma catalogação das obras de edição portuguesa, cuja circulação fora proibida durante o Estado Novo, tomou como base a Relação da Comissão, tendo a preocupação de fazer um levantamento bibliográfico em catálogos de várias bibliotecas. A autora chega à conclusão de que a informação fornecida pela Relação nem sempre fora suficiente, pelo que apenas 508 títulos da mesma haviam sido identificados, ficando cerca de 927 por localizar (Alvim 1999: 3).

Por sua vez, o investigador José Brandão disponibilizou uma relação de cerca de 900 títulos que, nas suas palavras, "constituem a maior recolha jamais realizada no âmbito da censura literária em Portugal” (Brandão 2001). Composta exclusivamente por obras de edição portuguesa, excluindo obras brasileiras e de outras proveniências, a sua lista abrange o período que vai de 1933 (ano da publicação do decreto-lei 22 469, que regulamenta a censura prévia às publicações gráficas) a 1974; e, além do título e do autor, inclui também informação relativa ao editor e à data de publicação. No entanto, nem no texto introdutório, nem na nota prévia é fornecida qualquer indicação acerca da proveniência dos dados que enumera e divulga, persistindo a dúvida se na base da sua investigação estará também a mesma Relação da Comissão do Livro Negro ou se o investigador se socorreu dos arquivos do Secretariado Nacional da Informação, Cultura Popular e Turismo (SNI), depositados no Arquivo Nacional da Torre do Tombo.

Para uma melhor identificação e para uma boa compreensão dos processos de censura à Livraria Moraes Editora, suas modalidades e especificidades, sobretudo enquanto editora católica conotada com as fações mais "progressistas" do Catolicismo ${ }^{8}$, tornou-se imperativo recorrer à matéria-prima, isto é, aos próprios relatórios de leitura feitos pelos censores aos livros editados pela Moraes, depositados no Arquivo Nacional da Torre do Tombo e, na sua grande maioria, acessíveis através da base digital Digitarq ${ }^{9}$. Lembre-se que o arquivo da editora se perdeu (Tamen 2006: 91), invalidando assim a hipótese de aceder, por exemplo, à correspondência trocada entre a editora e os Serviços de Censura e a outra documentação relativa a este assunto. Durante

8 Convém clarificar que a designação de "progressistas" dada a estes católicos é aqui usada por mera conveniência. Apesar de terem ficado conhecidos por este epíteto, este sempre foi posto em causa pelos próprios, pela forte carga ideológica que contém e que os integra num determinado sentido histórico: "O nosso combate era ao lado dos não-crentes, nunca separado deles. E, se rejeitávamos o chavão 'católicos progressistas', assumíamos publicamente o de 'católicos de esquerda.” (Costa 2003: 57)

9 Disponível em http://digitarq.arquivos.pt/ (consultado a 4/04/2016). Todos os relatórios doravante citados têm como código de referência $\mathrm{PT} / \mathrm{TT} / \mathrm{SNI}-\mathrm{DSC} / 35$. 
o processo de consulta aos arquivos do SNI, e por amabilidade de um dos seus responsáveis e das suas autoras, foi-nos facultada uma base de dados ${ }^{10} \mathrm{de}$ todos os relatórios de censura a livros depositados na Torre do Tombo. Com efeito, este é o primeiro levantamento detalhado feito a uma parte do acervo do SNI e permitiu uma localização mais eficiente e célere dos relatórios relativos à Moraes na Digitarq — tarefa que, sem qualquer outra referência, seria morosa, senão mesmo impossível ${ }^{11}$. Além do número do relatório, do título da obra e do autor, dela fazem parte outros campos como tradutor, editor, proveniência, despacho dado e observações.

No entanto, e ainda antes de nos determos no caso específico da Moraes, será interessante refletir um pouco sobre os dados recolhidos, uma vez que é provável que estes tenham sido até agora apenas usados para outras áreas de estudo, ficando desde já a sugestão de que seria proveitoso o estudo aprofundado e comparado destas tabelas, a fim de perceber os mecanismos do aparelho censório, a incidência e distribuição por anos e editoras, a proveniência das obras, os critérios adotados, etc. $\mathrm{O}$ período analisado compreende as décadas de 50, 60 e 70 (lembre-se que a Moraes começou a sua segunda vida em 1958 e, por isso, se acedeu apenas aos dados deste período) e o primeiro facto que salta à vista, nas listagens fornecidas, é a enorme quantidade de relatórios omissos no Arquivo Nacional da Torre do Tombo, de tal forma que o número ascende a cerca de $34 \%$ do total ${ }^{12}$, o que claramente indica que uma parte significativa deste acervo se perdeu ou está nas mãos de privados. Com efeito, no sítio de Internet Ephemera ${ }^{13}$, que alberga em modo digital a biblioteca e o arquivo pessoal de José Pacheco Pereira, encontram-se alguns destes relatórios de leitura (entre outros documentos), entre os quais o correspondente ao volume A quinta causa: católicos e direitos do homem de Salgado Zenha, precisamente da Editora Moraes, publicado e proibido em 1969. O proprietário do arquivo esclarece uma utilizadora do seu arquivo digital, explicando que "faziam parte do arquivo de uma figura de oposição ao regime de Salazar, cujo espólio adquiri já há muitos anos e que estava em

10 Trata-se do projeto "Tradução e censura durante o Estado Novo" das Doutoras Teresa Seruya e Maria Lin Moniz, do Centro de Estudos de Comunicação e Cultura, Universidade Católica Portuguesa.

11 O arquivo não está tratado arquivisticamente e, estando digitalizado, não pode ser consultado presencialmente.

12 A totalidade dos relatórios de leitura é facilmente deduzida pela numeração regular que seguiam. Entre 1950 e 1974 foram elaborados cerca de 6299 pareceres e destes cerca de 2137 estão em falta no arquivo. A título de exemplo, só no ano de 1973 faltam cerca de 303 relatórios num total de 667.

13 https://ephemerajpp.com/ (consultado a 31 de março de 2016). 
risco de poderem ir para fora de Portugal ${ }^{14}$. Se assim é, e se há e houve dispersão dos arquivos do SNI (e outros), importa deixar aqui um apelo para que a parte omissa deste património não desapareça definitivamente, para que de futuro se possa estudar com método e seriedade este período da nossa história recente.

Sem nos determos longamente na riqueza informativa oferecida por estes ficheiros, até por restrições de espaço e circunscrição do tema, uma breve análise aos dados dos mesmos revela que os anos em que foram pedidos mais pareceres a obras são precisamente os anos finais do regime, 1972 e $1973^{15}$, confirmando e deitando uma vez mais por terra "o mito de que a sanha persecutória baixou guarda com o marcelismo” (Melo 2005), cumprindo-se assim as instruções dadas por Gonçalo Rapazote, Ministro do Interior, em 1972, que apertava ainda mais o cerco a tipografias, livrarias e editoras ${ }^{16}$. Da mesma forma pode extrair-se a mesma conclusão no que diz respeito à Editora Moraes: foi precisamente no período do marcelismo que mais apreensões e proibições houve às obras publicadas.

Através da base de dados foi possível identificar um conjunto significativo de obras desta editora apreciadas pelos censores, tendo algumas delas sido proibidas de circular. Para algumas dessas obras existem inclusivamente pedidos de novos pareceres e um desdobramento de relatórios, expressando hesitações e dúvidas, o que mostra um modus operandi nem sempre eficiente e taxativo da máquina censória. Ao confrontar os títulos incluídos na Relação da Comissão do Livro Negro com a lista do investigador José Brandão e com os títulos dos relatórios encontrados no arquivo da Torre do Tombo, verificaram-se algumas discrepâncias e um aumento considerável do número de títulos proibidos da editora em estudo. Logo, cremos que não seja precipitada a inferência de que o mesmo se passe com as obras publicadas por outras editoras e a necessidade de elaborar uma relação exaustiva que cruze de forma sistemática todas as fontes e todos os documentos disponíveis.

14 Conforme se lê em http://ephemerajpp.com/2011/12/02/cwnsura-relatorio-no-7444-14-de-fevereiro-de-1964-relativo-a-o-hospede-de-job-de-jose-cardoso-pires/.

15 Em 1972 foram realizados 667 pareceres e proibidas de circular cerca de 111 obras, ou seja, cerca de $31 \%$ dos pareces existentes no arquivo; por sua vez, em 1973 foram elaborados 489 relatórios e proibidas 43 obras, cerca de $20 \%$ do total de relatórios consultáveis. Seria interessante fazer a mesma operação para os restantes anos.

16 Cf. Comissão do Livro Negro sobre o Fascismo 1980: vol. 1, 266-267. 


\section{Um olhar sobre os relatórios de censura aos livros publicados pela Moraes: alguns casos}

Em todos os textos memorialísticos deixados por António Alçada Baptista onde se evoca a história da Moraes e, por extensão, da revista $O$ Tempo e o Modo, é recordado o tema da censura, deixando claro que a censura prévia era um dos obstáculos maiores à publicação da revista:

o regime que existia na censura era o seguinte: as publicações periódicas iam à censura prévia e os livros não iam, mas podiam ser apreendidos. Nós, quando foi d'O Tempo e o Modo, para fugir a essa censura prévia, publicámos dois cadernos. O caderno sobre $O$ Casamento, se hoje o lermos vê-se que é de uma ingenuidade de catequese, no entanto, não podem imaginar o escândalo que foi a publicação desse caderno que a PIDE apreendeu. Depois publicámos um outro sobre Deus O Que É e que não foi apreendido (Baptista 1988: 98).

Num outro texto, Alçada Baptista refere que "a censura o que tinha de pior era a sua completa arbitrariedade. [...] era difícil adivinhar um critério para os cortes da censura e o pior é que as provas tinham que ser apresentadas já impressas" (Baptista 2000: 69), comentário que justapõe a umas tantas anedotas sobre cortes censórios às cegas, revelando o desprezo que sentia pela figura do censor, não só pelo que em si mesma representava, como pela fraca qualidade intelectual das pessoas a quem tal tarefa estava confiada:

a Sophia traduziu um texto de Shakespeare que terminava assim:

- O fantasma avança. - Pára-o! Fá-lo parar Marcelo!

A censura cortou essa linha (Baptista 2000: 69).

Mas as consequências da censura na vida da Moraes terão ido bem mais além do que as dificuldades criadas à publicação. Com efeito, a frágil situação económica em que desde logo a editora terá caído, devido à falta de assinantes e aos exemplares não-vendidos que se acumulavam nos armazén ${ }^{17}$, a ação da máquina censória sobre algumas das suas obras, proibindo-as, apreendendo-as e retirando-as de circulação, terá, porventura, agudizado ainda mais a sua já difícil situação financeira ${ }^{18}$. No já citado trabalho de José Brandão, é fornecido um gráfico ${ }^{19}$ com o top das editoras com mais livros proibidos,

17 O relato é feito na crónica anteriormente citada.

18 Para as consequências económicas das apreensões às editoras veja-se Pires 1977: 209.

19 Vd. http://expresso.sapo.pt/actualidade/os-900-livros-que-a-censura-proibiu=f720543 (consultado em 2016.03.31). 
surgindo a Moraes em 9. lugar. Refira-se que a maioria das editoras incluídas neste gráfico existia há bem mais tempo do que a Moraes, não sendo claro se o seu autor teve em consideração a proporção entre o arco temporal em que cada uma das editoras mencionadas operou e o número de obras apreendidas. Ainda assim, e com o número que entretanto se apurou, a Moraes deverá estar entre as editoras com mais obras apreendidas/proibidas.

No total, e depois de se cruzarem informações oriundas de várias fontes, algumas das quais, porém, não passíveis de serem verificadas pelas razões já explicadas, chegou-se a uma lista com 34 títulos proibidos/apreendidos pelos Serviços de Censura, todos eles publicados pela Livraria Moraes Editora desde a sua "refundação" até à Revolução dos Cravos. Este número não é, obviamente, definitivo, não sendo certo, pelas circunstâncias em que o arquivo do SNI chegou aos nossos dias, que um dia seja possível obter todos os títulos de obras e números absolutos.

Em consonância com um dos aspetos mais caraterísticos que define esta editora, a grande maioria das obras proibidas são obras ensaísticas traduzidas de outras línguas ${ }^{20}$ (sobretudo do francês, mas também do inglês e do italiano) e relacionadas com temas da atualidade, que cobrem âmbitos tão variados como a contestação política, a história, a moral e os costumes, a emancipação da mulher, o erotismo e a sexualidade, a religião, a ideologia (socialista e marxista), a pobreza. É precisamente a coleção que tem por nome "Temas e problemas", com 11 títulos, que é a mais atingida pela censura, seguida de "O Tempo e o Modo", a coleção que deu nome à revista, com seis títulos; e nem o emblemático "Círculo do Humanismo Cristão" escapa, com quatro títulos proibidos. As outras obras dividem-se por várias outras coleções, o que não é de estranhar visto a proliferação de coleções que faziam parte do projeto editorial de Alçada Baptista, por vezes à proporção de quatro obras para uma única coleção, como "Aventura interior", à qual pertencem os Manifestos do Surrealismo de André Breton, incluído na lista Brandão ${ }^{21}$.

$\mathrm{Na}$ maioria dos casos das obras proibidas publicadas pela Moraes foi localizado o respetivo relatório, cuja leitura atenta deixa entrever alguns detalhes significativos, que emergem das excrescências do trabalho burocrático confiado ao censor-leitor, que devia controlar, comparar, ler, redigir e justificar.

20 José Cardoso Pires defendia que os censores visavam principalmente o escritor nacional, revelando uma maior abertura aos autores estrangeiros e às obras traduzidas (in "O advogado da censura", Diário de Lisboa, 12/6/1976). Também dois estudiosos põem em causa que assim fosse (Azevedo 1997: 201; Seruya, Moniz e Rosa 2009: 122). A censura não se dedicava apenas às obras de conteúdo ideológico perigoso, mas também às obras literárias em geral.

21 Não foi possível verificar se tal obra foi efetivamente apreendida ou proibida. 
Não por acaso um deles, confrontado com um protesto de Alçada Baptista, alegando que fora proibida uma segunda edição de um livro cuja primeira edição já havia circulado livremente, chega mesmo a queixar-se de que os "Serviços não podem ter conhecimento de todos os livros que se editam no nosso País e que só podem, em boa verdade e justiça, ser moralmente responsáveis pela circulação dos que tenham sido submetidos à sua apreciação e julgamento ${ }^{22}$. O leitor-censor denuncia, assim, o seu próprio cansaço e, ao mesmo tempo que justifica a "falha" no sistema, acaba por denunciar a sua ineficiência. É sobre algumas destas obras e respetivos relatórios de leitura que agora nos iremos deter.

Seguindo os ditames legislativos e os princípios que guiavam a censura de livros ${ }^{23}$, entre os grandes temas em que as obras proibidas se podem incluir está, inevitavelmente, o comunismo ou tudo aquilo que tivesse a ver com a ideologia socialista. Desta forma, foram, previsivelmente, proibidas obras que, já no título, mostravam o lado a que pertenciam, por exemplo: O pensamento de Lenine de Henri Lefebvre, Os processos de Moscovo de Pierre Broué, $O$ marxismo como moral de José Luís Aranguren. O mesmo aconteceu ao livro Uma aldeia da China Popular, de Jan $\mathrm{Myrdal}^{24}$, apesar do seu primeiro censor hesitar e afirmar não ser fácil "dar uma opinião segura" sobre o livro, chegando mesmo a pedir uma segunda opinião, por se tratar de "um livro que merece ser meditado dado o alcance dos temas e problemas que levanta". O segundo censor prossegue com a atitude ambígua, oferecendo duas possibilidades: dar o livro como "Visto", sem autorizar ou proibir, havendo nesta hipótese a "vantagem em que a Censura se não apresente como intolerante proibindo um livro no qual a propaganda comunista é fraca”; ou proibir o livro, "o que se justifica pelo facto de a sua edição em português constituir uma especulação política oriunda de um sector que é fértil em atitudes indesejáveis". Apesar desta interessante preocupação pela boa imagem pública dos Serviços de Censura, o segundo leitor-censor opta pela proibição.

Este mesmo grupo "fértil em atitudes indesejáveis" daria a lume a primeira obra da pensadora francesa Simone Weil traduzida em Portugal, Opressão e liberdade, incluída na lista Brandão, mas cuja efetiva proibição não foi possível confirmar. No entanto, foi localizado o relatório relativo a uma obra

22 Quem o diz é o Capitão José Pereira de Mello, no relatório à obra $O$ fim da utopia de Herbert Marcuse, em 2/12/1970.

23 Cf. Gomes 2006: 68-69.

${ }^{24}$ PT/TT/SNI-DSC/35, Rel. no 7860 de 22/7/1966 e Rel. no 7860 (BIS) de 19/8/1966. 
anterior da mesma autora, Écrits historiques et politiques, na sua edição original, proibida e rotulada de pura "propaganda comunista"

Outro dos temas proibitivos dizia respeito à moral e aos costumes, ao erotismo e sexualidade e à emancipação da mulher. Neste âmbito, uma das obras mais emblemáticas da Moraes proibida de circular foi $O$ erotismo de Georges Bataille, uma "obra vasta de estudos com base filosófica sobre o 'erotismo", mas, contudo, "altamente nefasta" (rel. no 7880 de 29/9/1966). Outros exemplos são o polémico segundo caderno da revista $O$ Tempo e $o$ Modo, sobre o casamento, de cujo relatório apenas se encontrou apenas a capa, e O livro branco do aborto, da coleção do Le Nouvel Observateur.

Tudo o que respeitasse ao mundo estudantil e aos movimentos universitários era igualmente sancionado. Quando "o movimento estudantil começou a erguer-se contra o regime foi, por exemplo, proibida na imprensa a inclusão de palavras como 'juventude', 'estudante' e o próprio 'movimento estudantil'” (Pimentel 2007: 34). Neste âmbito encontramos a obra de Marcuse $O$ fim da utopia, com direito a dois relatórios: um para a edição brasileira ${ }^{26}$ e um para a edição portuguesa ${ }^{27}$. Ambas as edições foram proibidas de circular no país, tendo o editor reclamado da proibição, alegando que a edição portuguesa não deveria ser proibida, por não ser igual à brasileira. Embora ambas tenham em comum apenas uma parte (precisamente a que origina o título), Alçada Baptista tenta recorrer a uma estratégia, esperando que a diferente "montagem" do livro alterasse a sua essência aos olhos do censor. No entanto, tal não se verificou. A mesma sorte sofreu a obra Os estudantes, de Pierre Gaudez, traduzida em 1965 por Vasco Pulido Valente, que descreve e louva a ação da agremiação sindicalista dos estudantes franceses e onde, uma vez mais, há uma referência explícita à opção cívica e política dos editores da Moraes, que "enveredam por um caminho inconveniente e de nítida oposição à ética universitária nacional ${ }^{28}$ ". Não por acaso os católicos estiveram presentes nos movimentos académicos dos anos 60, lado a lado com comunistas, independentes e outros $^{29}$, fazendo ressoar também em Portugal os ecos do Maio de 68.

\footnotetext{
$25 \mathrm{PT} / \mathrm{TT} / \mathrm{SNI}-\mathrm{DSC} / 35$ Rel. no 6555 de 12/4/1960.

$26 \mathrm{PT} / \mathrm{TT} / \mathrm{SNI}-\mathrm{DSC} / 35$ Rel. no 8888 de 23/10/1967.

$27 \mathrm{PT} / \mathrm{TT} / \mathrm{SNI}-\mathrm{DSC} / 35$ Ofício ${ }^{\circ}$ 1841/70 de 2/12/1979.

$28 \mathrm{PT} / \mathrm{TT} / \mathrm{SNI}-\mathrm{DSC} / 35$ Rel. no 7554 de 22/5/1965.

29 Rezola 1996: 138.
} 


\section{Uma editora católica a braços com a censura}

Ao percorrer estas mais de três dezenas de relatórios, conclui-se que, ante a censura, os temas mais fraturantes do catálogo da Moraes são, sem dúvida, a paz e a religião, sendo estas as matérias que mais obras proibidas originaram. A título de exemplo, o relatório 7705 de 3/3/1966 refere apenas que Catolicismo de vanguarda (Domenach, Montvalon 1965) foi diretamente proibido "por ordem de S. Ex a o Subsecretário de Estado da Presidência do Conselho”, sem qualquer outra indicação. Domenach era um autor fundamental para o grupo da Livraria Moraes, enquanto ativista da primeira vaga de católicos progressistas na Europa ${ }^{30}$, pelo envolvimento, durante a guerra, contra a infiltração do nazismo na juventude francesa, pela organização da Resistência na Universidade de Lyon, e sobretudo pelo cargo de secretário de redação da revista $E s p r i t^{31}$, que servira de inspiração e modelo a $O$ Tempo e o Modo.

Ao folhear Catolicismo de vanguarda, não é difícil perceber o que é que nesta "vanguarda" incomoda ao censor: capítulos inteiramente dedicados a temas como "A luta contra o Colonialismo" e "A terra inteira, a sua violência e a sua paz" reportam diretamente para a ocupação francesa da Argélia, para as torturas praticadas, estendendo-se depois para toda a África Negra e Ásia $^{32}$. Um telegrama telefonado da Comissão de Exame Prévio do Porto de 27/1/1969 dá conta de quanto Domenach fosse persona non grata ao regime: "Jean-Marie Domenach - TUDO CORTADO. Está proibido de entrar em Portugal” (Príncipe 1979: 43).

Já na obra de Danilo Dolci, Para um mundo novo (relatório no 8132 de 22/8/1967), o leitor-censor Joaquim Palhares escuda a sua decisão numa impressão vaga de que no livro se defendem "teses pacifistas de suspeita intenção, se desenvolvem teorias católico-progressistas pouco construtivas e se apela para objeções de consciência subversivas", sem nunca, porém, descrever ou precisar que teorias e teses são essas. Com efeito, parece que apenas o epíteto "católico-progressista" e o adjetivo "pacifista" por si só põem o censor de pré-aviso, como sendo sinónimos certos de subversão.

30 Aliás, no catálogo da Moraes estão representados teólogos-chave da assim-chamada "primeira vaga" do Catolicismo progressista na Europa, como Mounier, Maritain, Marie-Dominique Chenu, Yves Congar, Teilhard du Chardin, entre outros (cf. Horn 2008).

31 Domenach juntou-se à Esprit a pedido de Emmanuel Mounier em 1946, e veio mais tarde a ser diretor ao lado de Alber Béguin, iniciando uma nova série de Esprit, por morte deste, em 1957.

32 Lembre-se em 1962 a assinatura do armistício entre França e Argélia, com contrapartidas para a França. 
Neste contexto, outra obra importante é A quinta causa - os católicos e os direitos do Homem: peças de um processo, de Francisco Salgado Zenha (relatório 8670, de 22/10/1969), publicado pela Moraes no mesmo ano, que remete na sua totalidade para peças processuais inclusas no procedimento criminal instruído pela $\mathrm{PIDE}^{33} \mathrm{em} 1959$ contra um grupo de católicos que, no dia 1 de março do mesmo ano, assinaram e divulgaram um manifesto impresso intitulado Os serviços de repressão do regime empregam métodos que uma consciência humana bem formada não pode tolerar e um espírito cristão tem necessariamente de repudiar. No documento, dirigido diretamente a Salazar, citam-se artigos estrangeiros onde se relatam casos de perseguição e de repressão policial nas colónias, denunciam-se métodos de tortura e de censura, louvando-se, concomitantemente, a coragem dos comunistas. Por fim, interpelam de forma desafiadora o Presidente do Conselho dizendo:

Senhor Professor Doutor Oliveira Salazar: Os signatários julgam interpretar o sentido de um largo sector da opinião pública e de um autêntico espírito cristão ao porem a V. Ex. ${ }^{a}$ e a si próprios um problema de consciência. $\mathrm{O}$ que expuseram é suficientemente grave e a doutrina que invocaram suficientemente clara para que, a V. Ex..$^{a}$ e a si próprios, já não seja legítimo um silêncio prudente ou um pretenso realismo político. [...] em nome dos princípios cristãos a que, como católicos, V. Ex. ${ }^{a}$ e eles próprios aderem acima de tudo, julgam dever da sua consciência exigir um esclarecimento amplo, total e definitivo às questões que levantam. Fazem-no sabendo que V. Ex. ${ }^{a}$ como político deverá um dia responder perante a História; e, sobretudo, como homem e cristão, terá de ser julgado por Deus (AAVV 1959: 29-30).

Assinado por 45 pessoas, entre as quais o Padre Abel Varzim, Alberto Vaz da Silva, António Alçada Baptista, Francisco Lino Neto, Francisco Sousa Tavares, João Bénard da Costa, Escada, Manuel de Lucena, M.S. Lourenço, Nuno Teotónio Pereira, Sophia de Mello Breyner, o livro está astutamente montado pelo autor, que foi também advogado de defesa dos réus, pois, de facto, tem apenas material processual já conhecido e constante dos autos que, na sua maioria, foi compilado e redigido pela própria polícia. O processo acabou por ser arquivado por despacho do juízo criminal, em consequência da amnistia decretada em 12/11/1960, mas o Capitão Pereira de Mello, ao fim de dez anos, proíbe veementemente a obra por tratar-se de:

33 O manifesto deu depois origem ao processo SC-PC-588/59, depositado no Arquivo Nacional Torre do Tombo. 
um panfleto de ataque político, de ataque imediato à P.I.D.E. e mediatamente, ao Governo que a instituiu, mantém e protege defensivamente, pois, segundo o Autor, o Governo é solidariamente responsável por todos os actos de violências ilegais imputados à P.I.D.E.. [...] Todo o folheto é uma obra de mal-intencionado ataque descabelado à instituição considerada uma das mais fiéis servidoras do regime político-social português, ataque que me parece (sobretudo nas actuais circunstâncias ou momento político) de impedir, com a proibição do panfleto inconvenientíssimo.

Uma outra obra cujo título já por si é perigoso, Cristianismo e marxismo no mundo de hoje (Paulus-Gesellschaft 1969), um colóquio-diálogo organizado pela sociedade Paulus-Gesellschaft em Salzburgo em 1965, onde participaram diversos teólogos cristãos e intelectuais marxistas, foi objeto de dois pareceres em anos consecutivos. No primeiro, de $1970^{34}$, o leitor-censor, amedrontado pelos argumentos "mais incisivos" apresentados pelos comunistas, propõe de imediato a proibição. No segundo, de $1971^{35}$, o texto do censor é, no mínimo surpreendente e até mesmo "progressista ${ }^{36 "}$ :

Todo o livro $[\ldots]$ assume um carácter especializado. Ora as pessoas já com opiniões formadas não parece que este livro venha alterar a sua forma de pensar. E os restantes não irão para além das primeiras páginas. Aliás, o tema é interessante e não parece possível querer impedir os portugueses de tomarem contacto com todos os problemas, invocando a sua falta de preparação.

No fim, o censor encerra o seu parecer concluindo que a circulação do livro deve ser autorizada. No entanto, num despacho manuscrito e assinado por outrem, é mantida a proibição.

Ainda antes do assassinato de Martin Luther King em 1968, mas já depois de ter recebido o Prémio Nobel da Paz em 1964, publicou a Moraes, em 1966, o seu primeiro livro de sermões Força para amar de 1963. Apesar do ataque feito ao comunismo ("o Comunismo e o Cristianismo são fundamentalmente

$34 \mathrm{PT} / \mathrm{TT} / \mathrm{SNI}-\mathrm{DSC} / 35$ Rel. no 8726 de 30/3/1970.

$35 \mathrm{PT} / \mathrm{TT} / \mathrm{SNI}-\mathrm{DSC} / 35$ Informação de serviço nº 58-DGI/GE de16/4/1971.

36 Ernesto Moura Coutinho é autor, neste ano, de outros pareceres semelhantes, onde se vislumbram alguns sinais de abertura e até de alguma lucidez. Veja-se o no 107-DGI/GE/71, acerca da obra Marx depois de Marx, de Pierre e Monique Favre: "O combate à penetração do ideário marxista não pode ser conduzido impedindo-se a divulgação de livros como o presente. Deverá antes promover-se o conhecimento de livros como aquele que se referiu”. Outro exemplo é o parecer 78-DGI/GE/71, sobre a obra A condição masculina e a emancipação da mulher, de Catherine Valabrègue: "Esporadicamente, faz-se a defesa do controlo de nascimentos e das experiências sexuais pré-conjugais, o que hoje em dia, embora discutível à luz da moral cristã, já de modo algum se pode considerar como chocante". 
incompatíveis [...] porque as duas filosofias são antitéticas” - King 1966: 164), criticam-se veementemente a Igreja e o colonialismo: "nem sempre a Igreja foi fiel à sua missão na questão da justiça racial; nesse campo, falhou miseravelmente perante Cristo. [...] Se a Igreja Cristã se tivesse realmente oposto, nunca o colonialismo teria durado tanto", afirmando mesmo mais adiante: "Quando os futuros historiadores disseram que, em pleno século $\mathrm{XX}$, a Igreja era um dos maiores baluartes da supremacia racial considerar-se-á isto, decerto, como um dos maiores dramas da história cristã" (King 1966: 170-171). Na contracapa alerta-se o leitor para o "grave momento de crise colectivo", mas nem o imperativo do amor, "no seu sentido mais lato, mais profundo e mais cristão" salvou a obra da apreensão.

Proibida de circular ${ }^{37}$ foi também a obra Evangelho e Igreja: a história do Isolotto, sobre o percurso da Comunidade de Isolotto, desde o nascimento da paróquia (1954) até ao processo por delito de perturbação de funções religiosas (1968-1969), descrevendo todas as suas ações pela paz. O processo deu-se na sequência do apoio dado à ocupação da Catedral de Parma por parte de um grupo de jovens católicos, a quem a comunidade escreveu uma carta:

Vivemos numa Igreja que não tem como alicerce os pobres, os oprimidos, os rejeitados, aqueles que têm fome e sede de justiça. A hierarquia e a parte oficialmente mais responsável da Igreja não pertencem ao mundo dos pobres, dos desprezados, dos oprimidos (Comunidade de Isolotto 1970: 140).

O no 8660 é atribuído a um relatório datado de 7/1/1970, que se refere ao opúsculo intitulado Se Cristo visse... Um grupo de cristãos escreve ao Papa, publicado pela Moraes em 1969, tradução de um manifesto assinado por um grupo de cristãos, em França, em 1968. Dizem os seus signatários:

Escrever para nós é um dever. Quereríamos derrubar este muro que vos separa do povo cristão e falar-vos com toda a franqueza. [...] O cristão tem atualmente necessidade de viver numa Igreja verdadeira; para ele a Igreja não é um simples enquadramento dentro do qual ele lá vai vivendo a sua vida espiritual a sós com Deus. Não! Para ele, viver em comunhão com Deus é inseparável de viver em comunhão com os irmãos, com a Igreja, com os homens. É por isso que tudo o que é falso, contradição com o Evangelho, escândalo na Igreja, é sentido pelo cristão de hoje, ao mesmo tempo como um golpe que o atinge no centro vital da sua fé e como uma doença do corpo eclesial que o debilita (AAVV 1969: 6-7).

37 De acordo com os Correios e Telecomunicações de Portugal, Direcção dos Serviços de Correios, em 11/5/1971 (cf. Príncipe 1979: 135). 
Mais adiante, e a partir desta premissa enunciada, são destacadas algumas contradições fundamentais, que denunciam e põem a descoberto factos como a intromissão na política por parte da Igreja, acusando-a de não ter renunciado ao seu poder temporal; o desrespeito pelos homens; a negação de Cristo e do seu voto de pobreza e, por fim, o falseamento da "Igreja Fraternidade" pela "Igreja-Sociedade", pela Igreja "que quer ser tudo".

Como se o seu conteúdo não fosse, por si só, problemático para os poderes então vigentes, na última página do mesmo opúsculo, contudo, o editor expõe-se ainda mais e imiscui-se na publicação através de uma pequena nota, que o torna cúmplice da provocação e agente da subversão, incitando diretamente os leitores à mobilização:

Esta carta foi inicialmente assinada por 744 cristãos, em França. Antes de ser tornada pública, foi entregue ao Núncio em Paris para ser transmitida ao Papa e foi também enviada directamente a Roma. Continua a fazer-se em França e começa a fazer-se em Portugal a recolha de assinaturas (que também serão transmitidas a Roma) de cristãos desejosos de fazerem ouvir a sua voz na Igreja. Podem enviar-se adesões (com nome e morada bem legíveis), para: "Carta ao Papa”: Av. 5 de Outubro, 297-1º DTO. Lisboa (AAVV 1969: s.p.).

Na Direcção-Geral de Segurança, a reação não se fez esperar e o processo teve um tratamento algo inusual. A primeira apreciação, do Capitão Pereira de Mello, propõe de imediato a proibição da obra, dizendo tratar-se de uma "especulação político-social-religiosa, de autoria anónima, mas de editor já desmascarado ou marcado", que constituía por si só "um ataque violento e virulento contra o Vaticano, nas suas duas personalizações integrantes: o aparelho eclesiástico e a mentalidade romana, ou seja: a orgânica e a tradução filosófico-religiosa da doutrina católica-apostólica-romana”. Logo no dia seguinte, uma informação urgente da Secretaria de Estado da Informação e Turismo, apensa ao primeiro relatório, pede mais informações sobre a mesma brochura, que se traduz numa segunda apreciação, manuscrita, no dia sucessivo. Nesta informação de duas páginas, é dito que a carta endereçada por um grupo de católicos progressistas franceses ao Papa fora divulgada meses antes pelo "movimento semiclandestino" GEDOC, tendo sido apreendida.

No entanto, as considerações feitas pelo censor-leitor não são tão taxativas e perentórias quanto se poderia pensar, deixando largas margens para a dúvida e expressando hesitações relativamente à posição a tomar. Na verdade, com este movimento, o próprio censor-leitor levanta as mesmas questões 
que se evocam no folheto e, sem querer, confirma as acusações diretamente feitas, numa súmula de ambiguidade e desorientação:

Poderá alegar-se que esta publicação tem só carácter religioso. Não é assim. Trata-se de um ataque cerrado à Igreja, procurando provar a existência dum compromisso entre a Igreja e a Política. A Igreja será um instrumento de manutenção da ordem política ao serviço do capitalismo. Há certa inconveniência na circulação deste folheto, que, no entanto, fará mais mal à Igreja do que ao Estado. Agradecerá, no entanto, aquela a sua apreensão? Ou virá depois clamar em favor da liberdade de Informação? É difícil emitir um parecer sobre o assunto. Pois se há bispos que são contra a censura! Conclusão: Não sei se é costume em casos como este consultar alguma autoridade religiosa. Não seria errado fazê-lo, para amanhã algum alto dignatário da Igreja não protestar contra os métodos da Censura e a falta de liberdade.

Uma importante conclusão a tirar e que emerge claramente destas palavras será que, por aquela altura, o preceito enunciado por José Timóteo Bastos, em 1926, que punha a Religião e o Estado de mãos dadas pelos tempos fora, começava a dar mostras de alguma fragmentação ${ }^{38}$, vendo-se o Estado na posição de ter de proteger a Igreja de si própria. E embora o pensamento e a ação continuada destes grupos, através de várias iniciativas e suportes, não se pudesse equiparar a uma verdadeira "desintegração gradual" do apoio católico ao regime, é inequívoco este "esforço ativo de uma minoria de católicos isolados" contra a "colaboração duradoura da Igreja institucional com o Estado Novo” (Simpson 2014: 230), tal como é inequívoco o seu efeito corrosivo no meio político e social de então.

\section{Notas finais}

É possível fazer um percurso pela história dos movimentos de contestação das décadas de 50 a 70 e compreender a razão pela qual a Moraes acompanha a história da oposição ao regime, fazendo parte de um processo de tomada de consciência cada vez mais alargado, dentro do qual se foram promovendo várias iniciativas e organizando diversos movimentos (Pereira 1994: 29). O início deste ciclo poderá ser marcado pela campanha eleitoral de Humberto Delgado em 1958, ano em que coincidentemente a Moraes começou a

38 "Religião e Estado, quase sempre bem-avindos pelos tempos fora, poucas vezes incompatíveis [...] conseguiram impor disciplinas de ferro ao intelecto humano pelo crime de insubmissão ou irrespeito àqueles dois poderes" (Bastos 1983: 15). 
sua atividade editorial, culminando, 14 anos depois, na ocupação da Capela do Rato. Alçada Baptista, "editor desmascarado ou marcado", e esse "grupo fértil em atitudes indesejáveis”, de acordo com os Serviços de Censura, eram efetivamente considerados uma ameaça, ficando claro que havia uma atenção particular às suas publicações e iniciativas, que expressavam em diversos planos uma preocupação de intervenção ideológica e cultural, ameaça essa materializada no grande número de obras proibidas/apreendidas.

Miller Guerra, na sessão parlamentar de 29 de julho de 1971, perguntava-se "Como é que a criação literária, artística, científica, as ideias sociais e políticas, numa palavra, a cultura intelectual, pode prosperar nos períodos históricos dominados pela censura?" (Guerra 1972: 309). A resposta prende-se, em primeiro lugar, pela relativa ineficácia da censura à literatura nacional e estrangeira, que dependia do acaso dos livros escolhidos, dos despachos superiores, das denúncias, das intervenções da polícia e da comunicação entre as várias delegações da censura espalhadas pela metrópole e pelas colónias. A isto aliava-se a subjetividade e a competência dos censores, pois através da sua escrita percebemos a oscilação dos critérios, as dúvidas. Se, por vezes, a decisão é óbvia, por vezes o censor hesita, tenteia o livro, abrindo-o com estilete e tenteando as suas vísceras com zelo e precaução.

Por outro lado, histórias como a da Moraes, livraria e editora, e seus projetos, sobretudo $O$ Tempo e o Modo, mostram que as ideias e os livros, apesar de todos os constrangimentos e do baixo volume de vendas, efetivamente circulavam, tendo deixado marcas profundas na história cultural do século XX português. Estes (e outros) livros influenciaram mentalidades, combateram também eles na guerra, participaram na revolução e ajudaram a depor ditadores. E é por isso que a história dos livros estará sempre, indelevelmente, ligado à história das pessoas, dos povos e até dos países.

\section{Bibliografia}

AAVV (1959). Os serviços de repressão do regime empregam métodos que uma consciência humana bem formada não pode tolerar e um espírito cristão tem necessariamente de repudiar. Lisboa: Moraes.

AAVV (1969). Se Cristo visse... Um grupo de cristãos escreve ao Papa. Lisboa: Moraes.

ALMEIDA, João Miguel (2008). A oposição católica ao Estado Novo (1958-1974). Lisboa: Nelson de Matos, 2008.

ALVIM, Maria Luísa (1999). Livros portugueses proibidos no regime fascista: bibliografia. Braga: Faculdade de Letras da Universidade do Porto. 
Associação dos Editores e Livreiros Portugueses (1974). Relação das obras cuja circulação esteve proibida em Portugal durante o regime Salazar/M. Caetano, de harmonia com as indicações que foram sendo fornecidos pelas direcções dos Serviços de Censura e Direção Geral de Informação. [S.1.]: AELP.

AZEVEDO, Cândido de (1977). Mutiladas e proibidas. Para a história da censura literária em Portugal nos tempos do Estado Novo. Lisboa: Caminho.

AZEVEDO, Cândido de (1999). A censura de Salazar a Marcelo Caetano. Lisboa: Caminho.

BAPTISTA, António Alçada (1988). "Vida e morte da Moraes”, Alter/Ego, 5, 93-98.

BAPTISTA, António Alçada (2000). A pesca à linha. Lisboa: Presença.

BARATA, Clara: QUEIRÓS, Luís Miguel (1994). “Os livros da resistência”, Público, 11/6, 1-4 (Suplemento Leituras).

BASTOS, José Timóteo (1983). História da censura intelectual em Portugal. 2a ed. Lisboa: Moraes.

BRANDÃO, José (2001). “Os 900 livros que a censura proibiu”, Expresso, 21/4, Em linha: http://expresso.sapo.pt/actualidade/os-900-livros-que-a-censura-proibiu=f720543 (consultado em 2016.02.12).

Comissão do Livro Negro sobre o Fascismo (1980). A política de informação no regime fascista. [S.1.]: CLNSRF.

Comissão do Livro Negro sobre o Regime Fascista (1981). Livros proibidos no regime fascista. [S.1.]: CLNSRF.

Comunidade de Isolotto (1970). Evangelho e Igreja: a história do Isolotto. Lisboa: Moraes.

COSTA, João Bénard da (2003). Nós, os vencidos do catolicismo, Coimbra: Tenacitas.

CRAVINHO, João (2004). “Compreender João Rabaça”, in Recordando José Rabaça. Lisboa: Multimédia.

DOMENACH, Jean-Marie; MONTVALON, Robert (1965). Catolicismo de vanguarda. Lisboa: Moraes.

FERRÃO, Manuela; OLIVEIRA, Susana; FONSECA, Teresa (org.) (2015). Livros proibidos no Estado Novo. $3^{\text {a }}$ ed. revista, Lisboa: Assembleia da República.

GOMES, Joaquim Cardoso (2006). Os militares e a censura. Lisboa: Livros Horizonte.

GUERRA, Miller (1982). Progresso na liberdade. Lisboa: Moraes.

HORN, Gerd-Rainer (2008). Western European liberation theology. The first wave 19241959. Oxford: Oxford University Press.

KING, Martin Luther (1966). Força para amar. Lisboa: Moraes.

LOPES, Joana (2007). Entre as brumas da memória. Pref. Pedro Tamen. Lisboa: Âmbar.

MEDEIROS, Nuno (2008). "Editores e Estado Novo: O lugar do Grémio Nacional dos Editores e Livreiros”, Análise Social, 43 (4), 795-815.

MELO, Daniel (2005). A comunicação distorcida (ou a censura exemplar ao jornal Notícias da Amadora, 1958-1974, Notícias da Amadora, 10/3. Em linha: http://64.71.144.19/nad/ artigodossaut.php eaid $=912 \&$ codaut $=$ censura 16\&lng $=$ pt $($ consultado em 2016.02.16). 
MORAIS, José Domingos (2007). “Uma açorda em Paris”, in AAVV, António Alçada Baptista. Lisboa: Presença e CNC, 110-116.

PAULUS-GESELLSCHAFT (1969). Cristianismo e marxismo no mundo de hoje. Lisboa: Moraes.

PEREIRA, Nuno Teotónio (1994). “O longo caminho até à Capela do Rato”, Seara Nova, 48/49/50, 29-32.

PIMENTEL, Irene Flunser (2007). “A censura”, in João Madeira (coord.), Vítimas de Salazar. $2^{a}$ ed. Lisboa: Esfera dos Livros, 33-71.

PIRES, José Cardoso (1977). E agora, José? Lisboa: Moraes.

PRÍNCIPE, Carlos (1979). Os segredos da censura. 3. a ed. Lisboa: Editorial Caminho.

REZOLA, Maria Inácia (1996). “Católicos progressistas”, in Fernando Rosas e J. M. Brandão de Brito (dir.), Dicionário do Estado Novo. Vol. 2. Venda Nova: Bertrand Editora, 137-139.

RODRIGUES, Graça Almeida - Breve história da censura literária em Portugal. Lisboa: ICLP, 1980.

SERUYA, Teresa; MONIZ, Maria Lin; ROSA, Alexandra Assis (org.) (2009). Traduzir em Portugal durante o Estado Novo. Lisboa: Universidade Católica Editora.

SIMPSON, Duncan (2014). A Igreja católica e o Estado Novo salazarista. Lisboa: Edições 70.

TAMEN, Isabel (org.) (2006). A aventura da Moraes. Lisboa: Centro Nacional de Cultura.

\section{Arquivos digitais consultados}

Digitarq: http://digitarq.arquivos.pt/

Ephemera: http://ephemerajpp.com/ 